\title{
純マグネシウム単結晶における 曲げ変形の結晶方位依存性
}

\section{北原 弘 基 ${ }^{1} \quad$ 津志田雅之 ${ }^{2} \quad$ 安 藤 新 二3,*}

1熊本大学パルスパワー科学研究所

熊本大学工学部技術部

3熊本大学先進マグネシウム国際研究センター

J. Japan Inst. Met. Mater. Vol. 80, No. 1 (2016), pp. 102-107

Special Issue on Frontier Researches Related to Nano/Microstructure, Microstructure Control and Mechanical Properties of Materials (C) 2015 The Japan Institute of Metals and Materials

\section{Orientation Dependence of Bending Deformation Behavior in Magnesium Single Crystals}

\author{
Hiromoto Kitahara ${ }^{1}$, Masayuki Tsushida ${ }^{2}$ and Shinji Ando ${ }^{3, *}$ \\ ${ }^{1}$ Institute of Pulsed Power Science, Kumamoto University, Kumamoto 860-8555 \\ ${ }^{2}$ Faculty of Engineering, Kumamoto University, Kumamoto 860-8555 \\ ${ }^{3}$ Magnesium Research Center, Kumamoto University, Kumamoto 860-8555
}

\begin{abstract}
Magnesium single crystals with different orientations were applied to three-point bending tests, and the bending deformation behavior was investigated. When the basal plane is parallel to the neutral plane, the specimens deformed due to basal slips. The specimens show gull-shape after deformation. On the other hand, when the neutral plane and the axis were parallel to (112̄0) and $[1 \overline{1} 00]$, the specimen deformed due to $\{10 \overline{1} 2\}$ twinning. However, it broke after a few percent of deformation, and then it showed V-shape. The specimen, whose neutral plane and axis are (112̄0) and [0001] also deformed due to basal slips. Relationship between bending yield stress of the specimens and CRSS of basal slip, or $\{10 \overline{1} 2\}$ twin was discussed.

[doi:10.2320/jinstmet.JB201515]
\end{abstract}

(Received August 31, 2015; Accepted November 13, 2015; Published December 11, 2015)

Keywords: magnesium, single crystal, bending, basal slip, $\{10 \overline{1} 2\}$ twin

\section{1. 緒言}

環境保護やエネルギー消費の低減を目的として，自動車等 の輸送機器の軽量化のために, マグネシウム合金の利用が検 討されている. そのような機器の部材としてマグネシウム合 金を利用する場合には，その塑性加工特性が問題となる。一 般にマグネシウム抢よびその合金は，高温では比較的良い延 性を示すが, 室温付近での延性はあまり高くないことが問題 となる. また圧延材や押出し材では集合組織形成に伴って, 引張の降伏応力と圧縮の降伏応力が大きく異なる1)といった 変形の異方性が生じることが知られている.このような挙動 は, マグネシウムの結晶構造が hcp 構造であるため結晶対 称性が低く, 容易なすべり系の数が限られており, さらに限 られた種類の双晶が活動することから生じるといえる。すな わちマグネシウムの主すべりは $\{0001\}\langle 11 \overline{2} 0\rangle$ 底面すべりで あり，その CRSS は約 $0.8 \mathrm{MPa}^{2}$ 程度と極めて低い。しか し底面すべりの等価なすべり面は 1 つしかないため, 例え ば荷重軸が $[0001]$ 軸に平行もしくは垂直な場合は，底面す

\footnotetext{
* Corresponding author, E-mail: shinji@msre.kumamoto-u.ac.jp
}

ベりに対するシュミット因子は 0 になり, 引張や圧縮にか かわらず，すべりを起こすことはできない。 また底面すべり についで容易な変形様式として $\{10 \overline{1} 2\}$ 双晶があり， $6.9 \mathrm{MPa}$ (1000 psi) 程度3)の低い応力で活動すると報告されている. しかしこの双晶は，[0001]軸に平行な引張もしくは垂直な 圧縮では生じることはできない，したがって，これ以外のい わゆる非底面すべりの活動が必要となる，そのようなすべり 系として $\{1 \overline{1} 00\}\langle 11 \overline{2} 0\rangle$ 柱面すべり4)や $\{11 \overline{2} 2\}\langle\overline{1} \overline{1} 23\rangle 2$ 次錐 面すべり5)があるが，それらの CRSS は底面すべりや双晶変 形に比べてかなり高い值を示す．このように多数の変形様式 があり, それらの変形応力が大きく異なることが, マグネシ ウムやその合金が変形に対して強い結晶方位依存性を示す原 因であるといえる.

このような変形挙動の理解のために, 一般的には引張試験 や圧縮試験による研究がなされているが, 曲げ変形に関する 研究は極めて少ない6). マグネシウムの板材から種々の部品 を加工する場合には，曲げ加工も重要なプロセスであること から，曲げ変形挙動を理解することも，マグネシウム合金の 利用に拈いて重要なことと考えられる. そこで本研究では, 曲げ変形における結晶方位依存性を調査するために, 純マグ ネシウム単結晶を用いた 3 点曲げ試験を行い, その変形挙 
動ならびに変形応力について検討することにした.

\section{2. 実 験 方 法}

市販の純度 $99.99 \%$ の純マグネシウム素材から, 高純度黒 鉛るつぼを用いて, 改良型ブリッジマン法により, 高純度ア ルゴンガス雾囲気中で単結晶を作製した．この単結晶の方位 をX 線背面反射ラウエ法により決定し, 硝酸を用いた無歪 切断機により角柱試験片を切り出し, 硝酸: 過酸化水素水: エタノール $=5: 7: 20$ からなる研磨液を用いた酸研磨盤に より表面を平滑にし, 寸法約 $3 \mathrm{~mm} \times 3 \mathrm{~mm} \times 25 \mathrm{~mm}$ に仕上 げた. 加工した試験片は, 加工中の歪を取り除くために熱サ

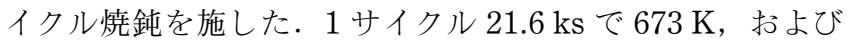
$723 \mathrm{~K}$ で $1.8 \mathrm{ks}$ 保持し，その温度間を $5.5 \times 10^{-3} \mathrm{~K} / \mathrm{s}$ で変化 させるものであり，これを 8 サイクル行った。作製した試 験片の方位を Fig. 1 に示す．A 試験片およびB 試験片は, 中立面が $(0001)$ に平行であり中立軸がそれぞれ $[1 \overline{1} 00]$ 㧍よ び $[11 \overline{2} 0]$ である.C 試験片は $[0001]$ 軸が中立面に平行で, 中立軸に垂直であり，D 試験片は $[0001]$ 軸に中立軸が平行 である.すなわち，図中に示したように，いずれの試験片も 3 点曲げ変形で生じる圧縮㧍よび引張の応力に対して底面が
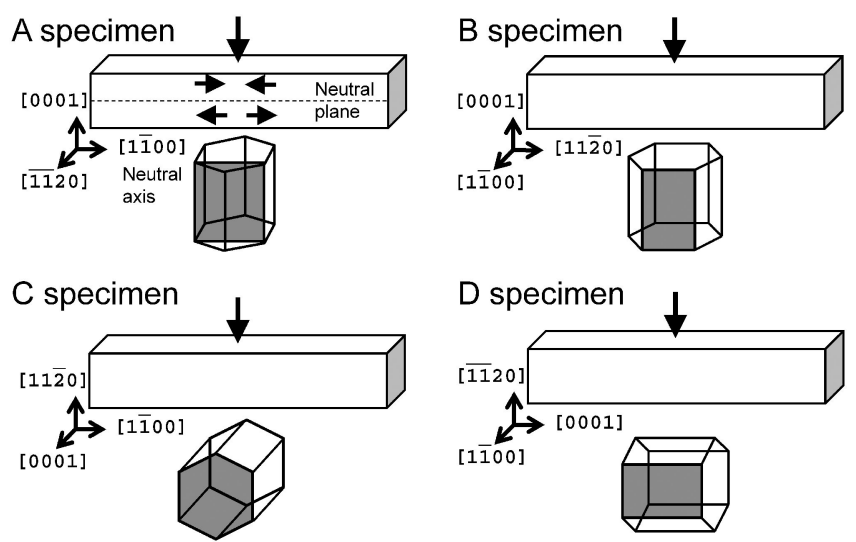

Fig. 1 Schematic illustrations of four kinds of $\mathrm{Mg}$ single crystals with different crystal orientations.

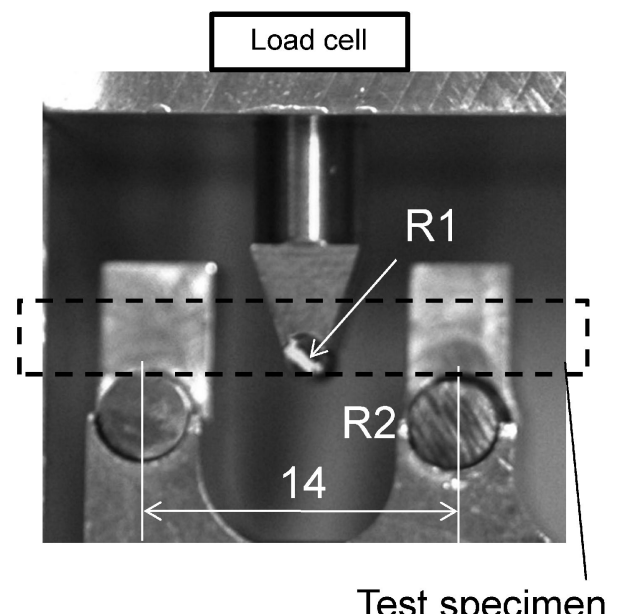

Fig. 2 Photograph of three-point bending device used in this study. (Unit: $\mathrm{mm}$ )
平行もしくは垂直となり，底面すべりのシュミット因子が 0 となる方位を選定した． 3 点曲げ試験は，Fig. 2 に示すよう な, スパン $L=14 \mathrm{~mm}$, 支持部の半径が $2 \mathrm{~mm}$, 中央圧子先 端の半径が $1 \mathrm{~mm}$ の小型試験装置を用いて行った. 中央圧子 の押込及速度は $1.67 \times 10^{-2} \mathrm{~mm} / \mathrm{s}$ とし, 室温大気中で試験 を行った．試験中抢よび試験後の表面はノマルスキー型微分 干渉顕微鏡により観察した. また圧子に取り付けたロードセ ルの荷重 $P$ から, 次式を用いて曲げ応力 $\sigma$ を評価した.

$$
\sigma=3 P L /\left(2 b h^{2}\right)
$$

ここで $b$ 抢よび $h$ は, それぞれ試験片の厚さおよび高さで ある.

\section{3. 実 験 結 果}

各試験片の曲げ応力-変位曲線を Fig. 3 に示す。 また各試 験片の寸法と降伏時の荷重 $P_{\mathrm{y}}$ 抢よび曲げ降伏応力 $\sigma_{\mathrm{y}}$ の值を Table 1 に示す．A 抢よびB 試験片の曲線の形状は同様であ り, それぞれ $18.1 \mathrm{MPa}$ 抢よび $12.2 \mathrm{MPa} て ゙$ 降伏した。降伏 後は小刻反な応力変動と数回の大きな応力落下が見られる が，全体的には緩やかに加工硬化した．Ａ打よび B 試験片 に曲げ変位を，それぞれ $3 \mathrm{~mm}$ 打よび $4 \mathrm{~mm}$ まで負荷した点 で試験を中断したが，破断してはいなかった。C試験片は $32.3 \mathrm{MPa}$ および $33.2 \mathrm{MPa}$ で降伏し, 変位約 $0.4 \mathrm{~mm}$ まで 応力が小刻みに上下しながら加工硬化した. その後は急速に 急激に応力が上昇し, 変位約 $1 \mathrm{~mm}$, 曲げ応力約 $180 \mathrm{MPa}$ に扔いてき裂が発生した。 D 試験片は, $6.4 \mathrm{MPa}$ 抢よび $12.3 \mathrm{MPa}$ で降伏したが，その後はほとんど加工硬化を示さ

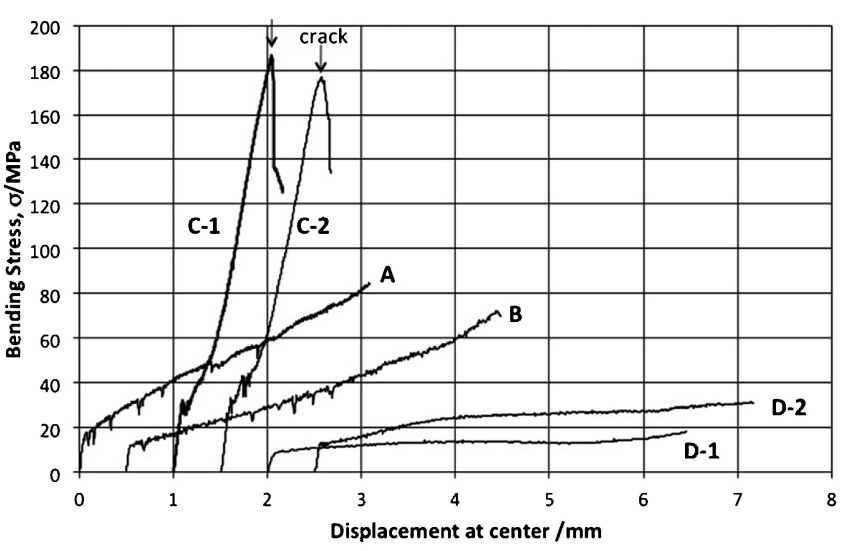

Fig. 3 Bending stress-displacement curves of the specimens.

Table 1 Specimen sizes of the specimens and the bending properties.

\begin{tabular}{ccccccc}
\hline Specimen & $L / \mathrm{mm}$ & $b / \mathrm{mm}$ & $h / \mathrm{mm}$ & $P_{\mathrm{y}} / \mathrm{N}$ & $\sigma_{\mathrm{y}} / \mathrm{MPa}$ & $\tau_{y x} / \mathrm{MPa}$ \\
\hline $\mathrm{A}$ & 14.0 & 2.43 & 2.93 & 18.0 & 18.1 & 1.09 \\
\hline $\mathrm{B}$ & 14.0 & 2.54 & 2.46 & 8.9 & 12.2 & 0.71 \\
\hline $\mathrm{C}-1$ & 14.0 & 3.34 & 3.09 & 49.0 & 32.3 & - \\
\hline $\mathrm{C}-2$ & 14.0 & 2.70 & 3.17 & 42.9 & 33.2 & - \\
\hline $\mathrm{D}-1$ & 14.0 & 3.72 & 3.52 & 14.0 & 6.4 & 0.53 \\
\hline $\mathrm{D}-2$ & 14.0 & 2.47 & 3.27 & 15.5 & 12.3 & 0.96 \\
\hline
\end{tabular}


ず，変位 $4 \mathrm{~mm}$ まで破断することなく変形した．この結果か

ら，結晶方位により曲げ変形挙動が大きく異なることがわか る.

この変形挙動の違いを試験片側面の観察に基づいて比較し た. Fig. 4 に A および B 試験片の試験後の外観を示す。い ずれも破断することなく変形しており，底面に平行な底面す べりのすべり線が生じていた。 またすべり線は両支持部の間 に集中しており，試験片は「ひ」の字型に变形していること がわかる。また圧子の下部付近からから両側に双晶が生じて いる. Fig. 5(a)〜 (c)に，この双晶部，圧子の下部抒よび支 持部上部付近を拡大したものをそれぞれ示す. Fig. $5(\mathrm{a})$ に 示すように，双晶内部に生じたすべり線と母相のすべり線の 角度，および双晶の角度より，この双晶はマグネシウムで容 易に生じる $\{10 \overline{1} 2\}$ 双晶であることがわかった。 また Fig. 5 (b)で示すように，圧子の直下にはすべり線が見られず，す ベり線はその両側に広がっている，このすべり線は，左右の 支持部まで広がっているが，Fig. 5(c)に見られるように， その外側ではほとんど生じていなかった。この様子は B 試 験片でも同様であった。

(a) A specimen

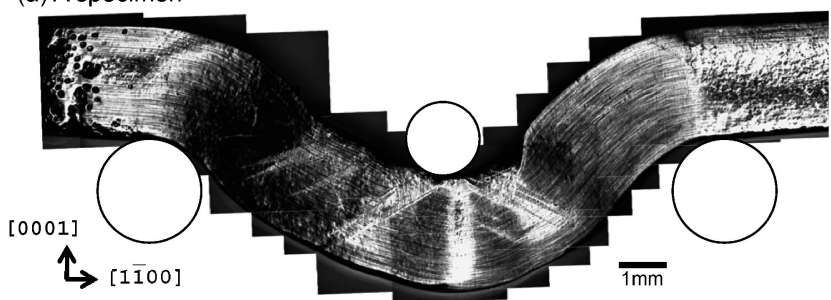

(b) B specimen

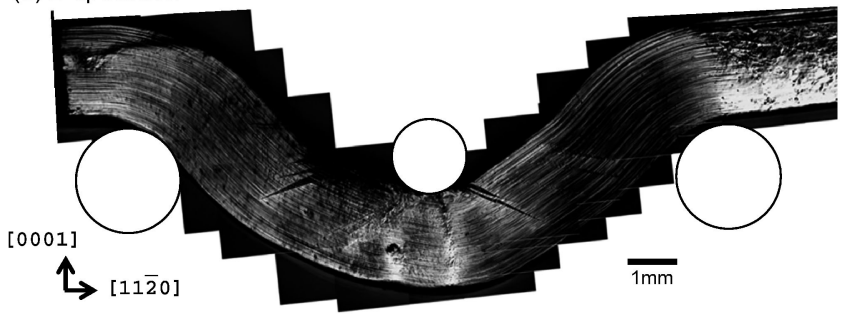

Fig. 4 Optical micrographs of (a) A and (b) B specimens after bending test.
Fig. 6 に，B 試験片の降伏時の中央圧子直下のすべり線を 示す．降伏直後のわずかな変形においても，圧子下部から試 験片の下面側まで短いすべりが生じていることがわかる。こ のすべり線は変形が進むにつれ試験片の左右に広がっていっ た。 またそれに伴いFig. 5(a)に見られる双晶が発生した. Fig. 3 の応力-变位曲線に見られた大きな応力変動はこの双 晶によるものと考えられる。しかし双晶変形の領域は，試験 片の全体に比べて小さいことから，A および B 試験片は， 主に底面すべりによって変形しているといえる。

次に C 試験片の様子を Fig. 7 に示す。（a）ようにわずか に V 字型に変形した後, 試験片中央部下面からき裂が生じ た。（b）に試験片上面側の側面を拡大したものを示す．圧縮 応力が働く試験片の上面側には (1102) 双晶が密集して発生 していることがわかる．マグネシウムでは底面に平行な圧縮 により $\{10 \overline{1} 2\}$ 双晶が生じることが知られて抢り ${ }^{3)}$ ，また (b) の双晶の方向から，これらは (1102) 双晶であると判断し た。この $(1 \overline{1} 02)$ 双晶の下端は引張応力が作用する試験片下 面側まで伸びていた。また $(\mathrm{c})$ 抢よび (d)には，き裂部を側

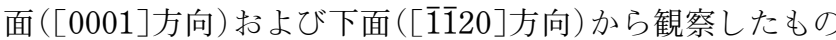
である。この 2 面観察より，破断面は (10̄11)面であること がわかった. Fig. 8 に降伏における応力落下を示した後, $0.1 \mathrm{~mm}$ 程度変形させたときの中央圧子近傍の様子を示す.

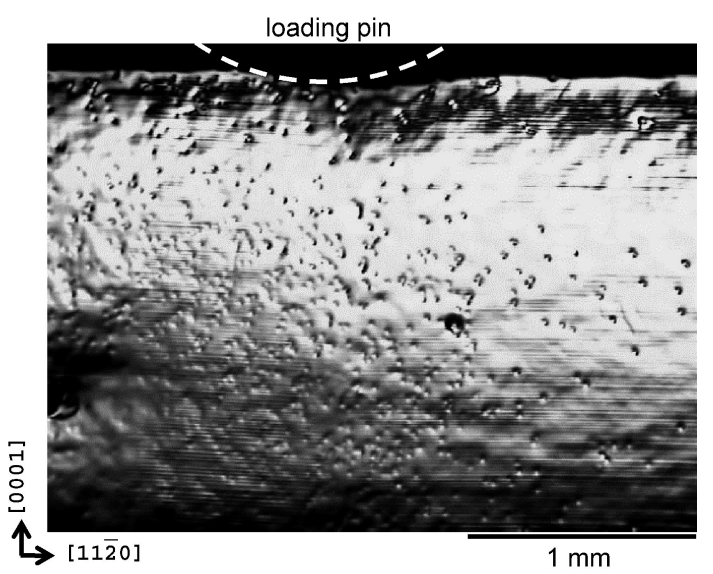

Fig. 6 Optical micrograph of slip lines at the center area of B specimen beneath the loading pin at yielding. (a)

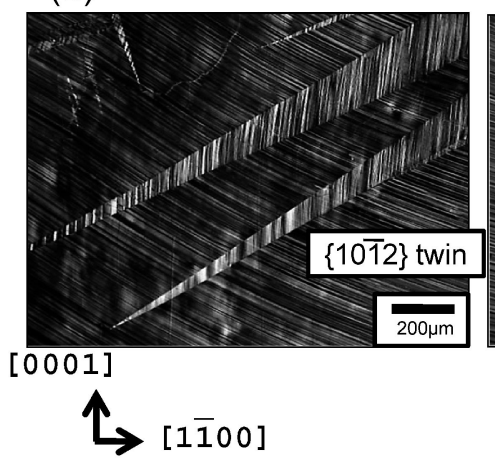

(b) loading pin

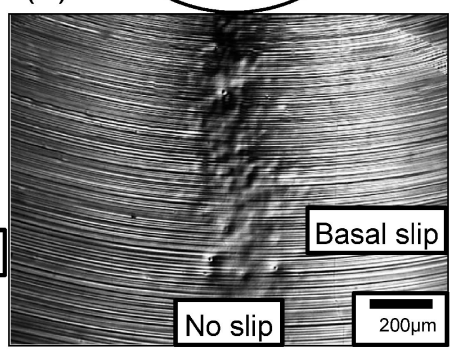

pum (c)

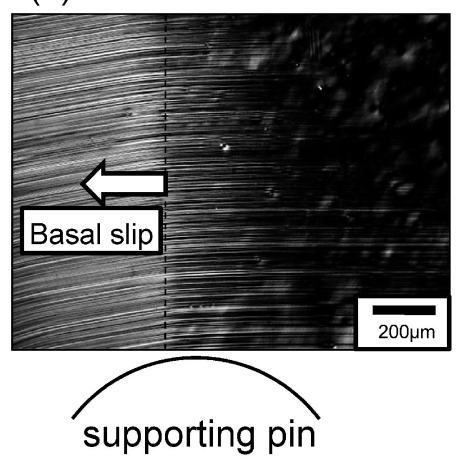

Fig. 5 Optical micrographs of (a) twins, basal slip lines at areas beneath the loading pin (b) and above the supporting pin (c) on the surface of A specimen. 
(a)

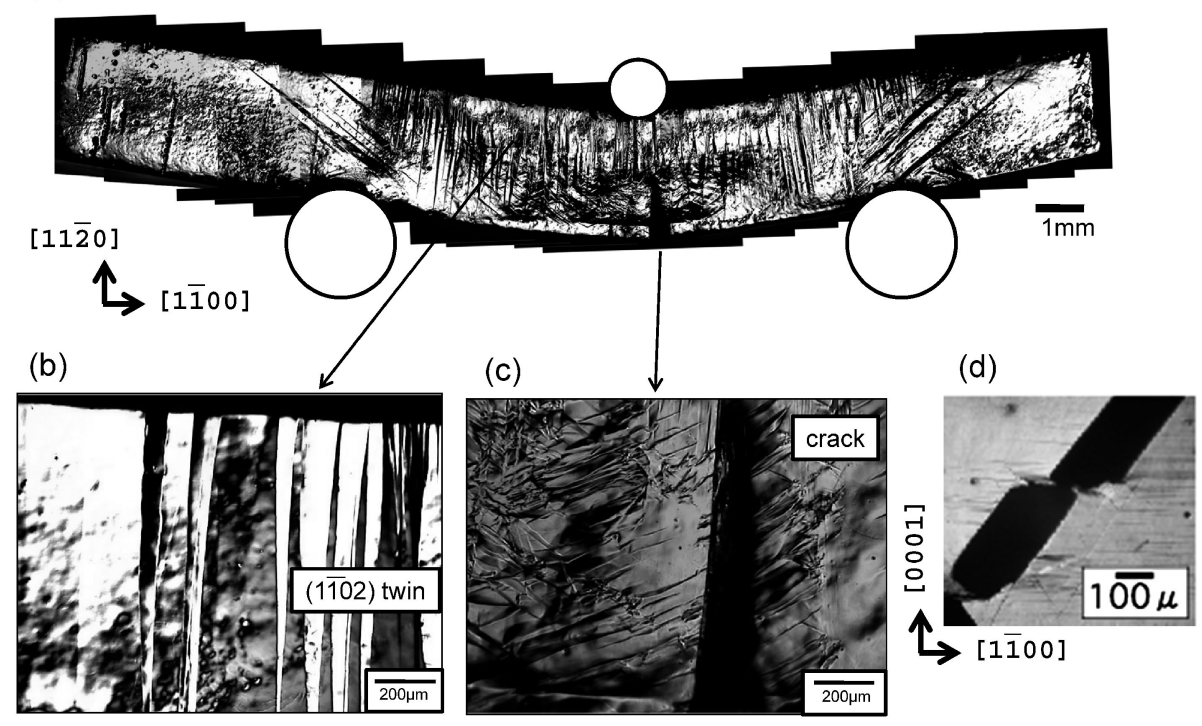

Fig. 7 Optical micrographs of (a) appearance of C specimen, (b) $\{10 \overline{1} 2\}$ twins and a crack observed from (c) [0001] and (d) $[\overline{1} \overline{1} 20]$ after the bending test.

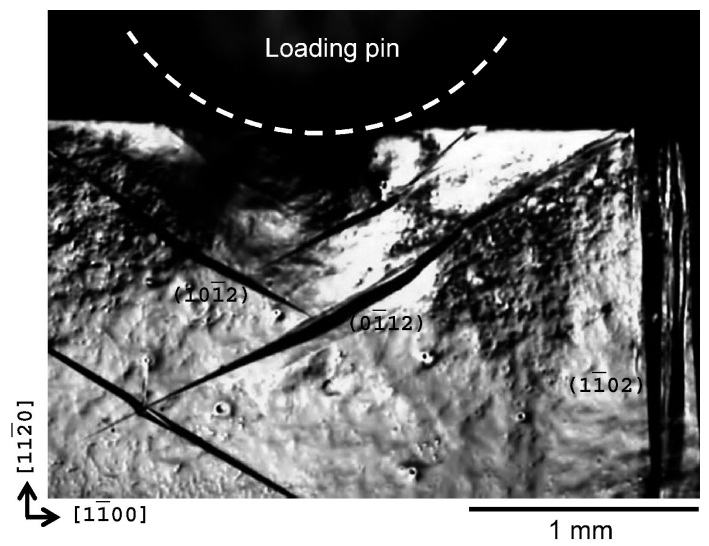

Fig. 8 Optical micrograph of $\mathrm{C}$ specimen beneath the loading pin after the stress drop by yielding at a displacement of about $0.1 \mathrm{~mm}$.

最初圧子下部に $(10 \overline{1} 2)$ 双晶抢よび $(0 \overline{1} 12)$ 双晶が生じた後, 中央圧子と両端の支持部の間で生じた $(1 \overline{1} 02)$ 双晶が徐々に 左右に広がっていった．そして Fig. 7 (a)に示したように, この (1102) 双晶が試験片の上面を埋め尽くしたとき，下面 でき裂が発生した。

最後に D 試験片の様子を Fig. 9 に示す. 中央部を $4 \mathrm{~mm}$ 程度変形させても破断することなく，(a)のように V 字型に 変形した（b)に示すように中央圧子の下部，および (c)の 右側に見られるように, 支持部付近には $\{10 \overline{1} 2\}$ 双晶が発生 しているが，(c)に見られるような縦方向に多量の底面すべ りのすべり線が観察された．したがって D 試験片は主に底 面すべりによって変形していることがわかった.

以上，4つの方位の試験片を曲げ試験した結果， A，B B よび D 試験片はいずれも底面すべりで変形するが，変形後 の形状には違いが生じ, また C 試験片は $\{10 \overline{1} 2\}$ 双晶で変形 することがわかった。 すなわち, 曲げ変形において, 変形挙 動に強い結晶方位依存性があることがわかった。

\section{4. 考察}

すべり線観察結果より，マグネシウム単結晶の変形挙動は 強い結晶方位依存性を示すことがわかった．またFig. 3 に 示したように，曲げ試験における変形応力も結晶方位ごとに 大きく異なった．ここでは各試験片の変形応力と活動した変 形機構の関係を考えることにする.

まず $\mathrm{A}$ および $\mathrm{B}$ 試験片は $12 \sim 18 \mathrm{MPa}$ 程度の曲げ応力で 降伏した. この曲げ応力は, 試験片に生じる圧縮および引張 応力に相当するが，この応力に対する底面すべりのシュミッ 卜因子は 0 であるため, シュミット因子では曲げ降伏応力 と底面すべりの CRSS との関係は説明できない。ここです ベり線観察結果から推定した $\mathrm{A}$ および $\mathrm{B}$ 試験片における変 形機構の模式図を Fig. 10(a)に示す. 図に示したように座標 軸をとると, 試験片中の底面に働くせん断力は $\tau_{x y}$ と表せ, これは点線で示す面のせん断応力 $\tau_{y x}$ と等しくなる. したが って $\tau_{x y}$ は次式で求められることになる.

$$
\tau_{x y}=\tau_{y x}=(P / 2) /(b h)
$$

ここで A 試験片では，中立軸方向すなわちせん断力が働く 方向が $[1 \overline{1} 00]$ であり，底面すべりのすべり方向とは $30^{\circ}$ 異な るため荷重は $P \cos 30^{\circ}$ とする：このことを考慮すると Table 1 に示すように $\tau_{y x}\left(=\tau_{x y}\right)$ は $1.09 \mathrm{MPa}$ および 0.71 $\mathrm{MPa}$ となった。これは底面すべりの $\mathrm{CRSS}^{2)}$ とほぼ一致す る。すなわち $\mathrm{A}$ および $\mathrm{B}$ 試験片の曲げ降伏応力は，底面に 作用するせん断変形に支配されていることがわかる.

ここで $\mathrm{A}$ 抢よび $\mathrm{B}$ 試験片は, 試験片の両端が拘束されて いないにもかかわらず，Fig. 4 のような形状に変形した理由 を考える. 通常の曲げ試験では, 支持部の間の上下で圧縮変 形および引張変形が生じ, その結果 $\mathrm{V}$ 字型に変形するとい える。しかし A および B 試験片での変形は, 中立面に平行 な底面に沿ったせん断変形である点が大きな特徴である，こ の場合 Fig. 10 (b)に示すように, 圧子下部付近の底面上の 
(a)

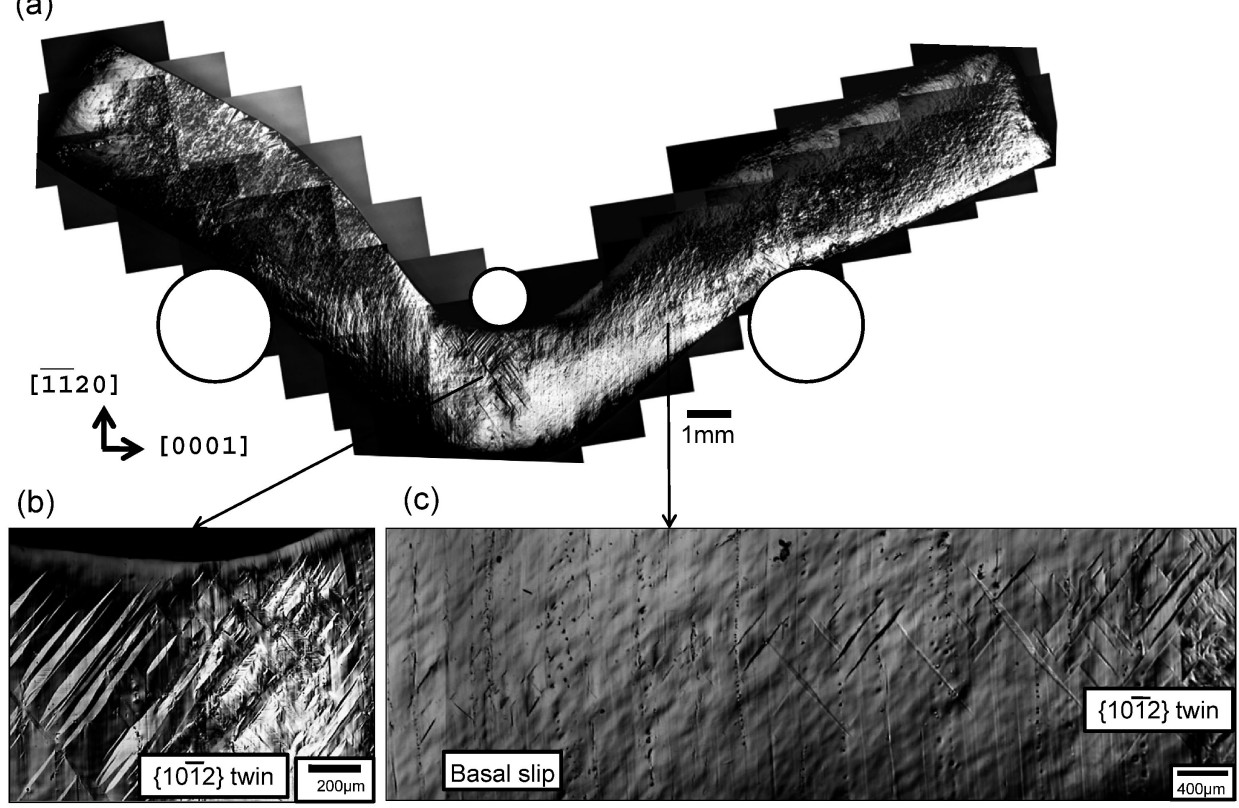

Fig. 9 Optical micrographs of (a) appearance of D specimen and $\{10 \overline{1} 2\}$ twins beneath the loading pin (b) and near the supporting pin (c) after the bending test.
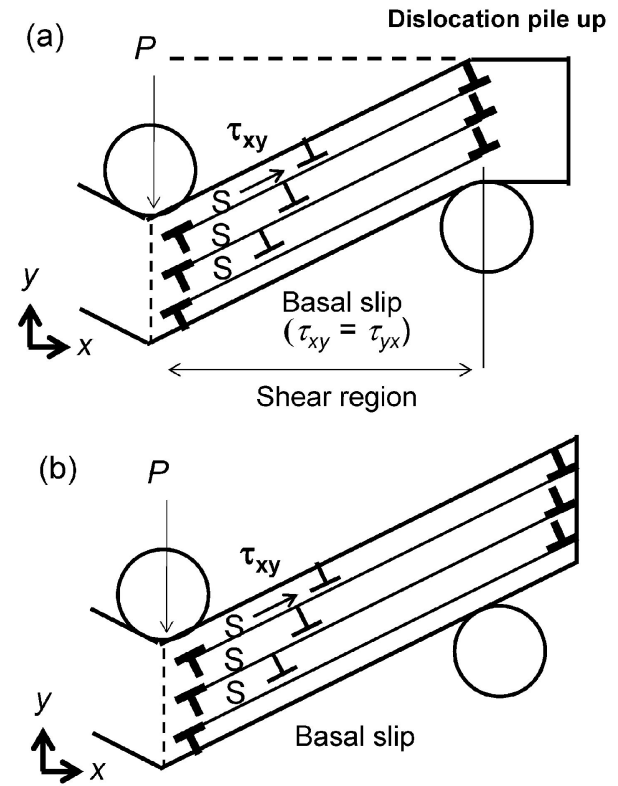

Fig. 10 Illustrations of deformation mechanisms in (a) A and $\mathrm{B}$ specimens showing gull-shape and (b) a specimen when dislocations on basal planes glide to its edge.

転位源から増殖した転位がすべり面上を運動し，試験片の両 端まで到達すれば，試験片は V 字型の形状になると考えら れる。しかし Fig. 4 で分るように，すべり線は両支持部ま でしか観察されない，すなわち，底面上の転位は支持部付近 に扔いて何らかの理由で運動が阻害されたと考えられる。せ ん断変形が進行するとこの部分に転位が堆積し傾角粒界のよ うになるため，Fig. 10(a)のように，この部分で結晶が曲が り，最終的に Fig. 4 のような形状になったと考えられる. また底面上の転位がパイルアップするため, 変形の進行に伴 いより多くの転位を増殖させるためには高い応力が必要とな り，応力一变位曲線に見られるように加工硬化を示したとい

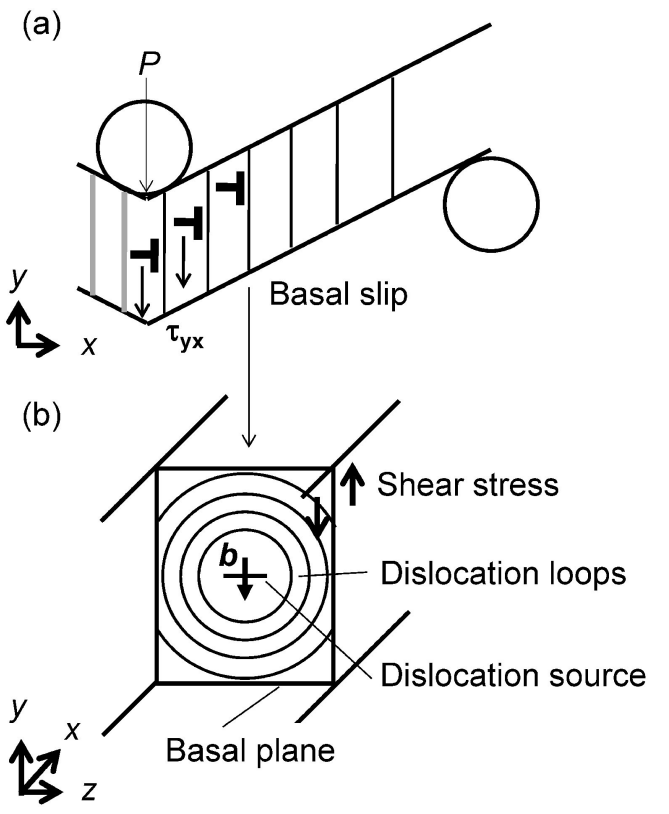

Fig. 11 Illustrations of (a) dislocation glides under the bending test and (b) the generation of dislocations on a basal plane, in $\mathrm{D}$ specimen.

える。しかし，なぜ支持部で転位の運動が妨げられたのか は，今後の検討を要する。

次に同様に底面すべりが生じた D 試験片について考え る.この場合，Fig. 11(a)に示すように，圧子の押し込及方 向と底面すべりの方向が一致して抢り，底面上のせん断力は

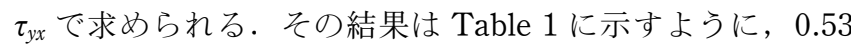
$\mathrm{MPa}$ 打よび $0.96 \mathrm{MPa}$ となり，これらは底面すべりの CRSS とほぼ一致している．したがってこの降伏応力は底面 すべりの CRSS に依存するものであり，D試験片の変形は $\mathrm{A}$ および $\mathrm{B}$ 試験片と同様に，底面に沿ったせん断変形であ るといえる．ここで Fig. 3 の曲げ応力-变位曲線では，A 扔 
[1̄̄00] compression

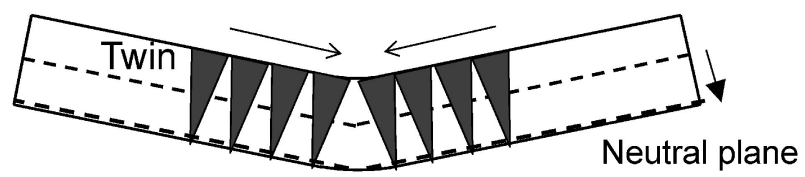

Fig. 12 Illustration of deformation mechanism in $\mathrm{C}$ specimen.

よび B 試験片とは異なり， D 試験片はあまり加工硬化を示 さず変形している，その理由を次のように考えた.

Fig. 11(b)に示すように, 荷重を負荷すると底面に沿って せん断応力が作用し, それにより底面上の転位源が活動し, 転位ループを増殖することになる。試験片は単結晶であり, 転位の運動方向に対して, 運動を妨げるものがないために, すべりの進行に伴い先頭の転位ループは結晶外に抜け出るこ とになる，そこで，すべり面上にある一定量の転位が分布し た状態で定常的なすべり変形が進行すると考えると, 変形応 力は一定の值となると考えられる. しかし, この機構が妥当 であるかを検証するには，今後転位分布の観察等が必要であ る.

最後に $\{10 \overline{1} 2\}$ 双晶で変形した $\mathrm{C}$ 試験片について考える.

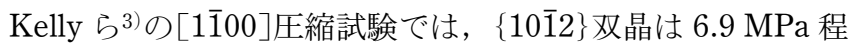
度で起こるとしている. Fig. 7(b)で示した，C試験片の上 面を占めた $(1 \overline{1} 02)$ 双晶に対し, 曲げ応力は $[1 \overline{1} 00]$ 圧縮に相 当するが，その曲げ降伏応力は $33 \mathrm{MPa}$ 程度であり, Kelly らの圧縮試験における值と大きく異なっている.ここで C 試験片の変形の模式図を Fig. 12 に示すが，圧縮側から発生 した双晶が反対の引張側まで到達している. すなわち, 双晶 による試験片の変形は圧縮側のみであり, 引張側では生じて いないと考えると，変形を生じない中立面が，C試験片では 引張側の方に移動したとみなせるのではないかと考えた．そ の場合, 式(1)に抽, 試験片の高さ $h$ は 2 倍となるため 曲げ応力は $1 / 4$ になり, 圧縮側で約 $8 \mathrm{MPa}$ 程度の応力が生 じていることになる．この值は上述の双晶変形に必要な応力
にほぼ一致しており, 双晶の変形応力と曲げ変形応力が関連 することを強く示唆している. しかしながらこの評価の妥当 性を示すには, 変形時の試験片の圧縮および引張側における 歪や応力を詳細に調査する必要があると考えられる。

\section{5. 結言}

純マグネシウムの変形機構を理解するために, 単結晶を用 いて曲げ変形における変形挙動の方位依存性を調査した。そ の結果, 中立面が $(0001)$ に平行であり, 中立軸がそれぞれ [1100]抢よび $[11 \overline{2} 0]$ であ A および B 試験片は，いずれも 底面すべりにより変形し, 加工硬化を示すことがわかった。 [0001]軸が中立面に平行で, 中立軸に垂直である C 試験片 では， $\{10 \overline{1} 2\}$ 双晶によって变形するが，わずかに变形した 後破断した．中立軸が $[0001]$ 軸に平行で，中立面が $(11 \overline{2} 0)$ である D 試験片は底面すべりにより変形するが，ほとんど 加工硬化は示さないことがわかった．またそれぞれの試験片 の変形応力は, 底面すべりおよび双晶変形の CRSS と関係 があることを示すことができた。

本研究の一部はJSPS 科研費 21560688 および 25870556, ならびに (公財) 軽金属奨学会の補助金により実 施したものであり，ここに深く感謝の意を表する.

文献

1) M. R. Barnett, Z. Keshavarz, A. G. Beer and D. Atwell: Acta Mater. 52(2004) 5093-5013.

2) H. Asada and H. Yoshinaga: J. Japan Inst. Metals 23 (1959) 649652.

3) E. W. Kelly and W. F. Hosford, Jr : Trans. Metal. Soc. AIME 242 (1968) 5-13.

4) F. E. Hauser, P. R. London and J. E. Dorn: Trans. Metal. Soc. AIME 206 (1956) 589-593.

5) S. Ando, K. Nakamura, K. Takashima and H. Tonda: J. JILM 42 (1992) $765-771$.

6) I. Aslam, B. Li, Z. McClell, S. J. Horstmeyer, Q. Ma and P. T. Wang: Mat. Sci. Eng. A 590(2014) 168-173. 